$1-2005$

\title{
Holding High Hopes: How High Schools Respond to State Accountability Policies
}

Margaret E. Goertz

University of Pennsylvania, Pegg@gse.upenn.edu

Diane Massell

Follow this and additional works at: https://repository.upenn.edu/cpre_policybriefs

Part of the Curriculum and Instruction Commons, Educational Administration and Supervision Commons, Educational Methods Commons, and the Education Policy Commons

\section{Recommended Citation}

Goertz, Margaret E. and Massell, Diane. (2005). Holding High Hopes: How High Schools Respond to State Accountability Policies. CPRE Policy Briefs.

Retrieved from https://repository.upenn.edu/cpre_policybriefs/29

View on the CPRE website.

This paper is posted at ScholarlyCommons. https://repository.upenn.edu/cpre_policybriefs/29

For more information, please contact repository@pobox.upenn.edu. 


\title{
Holding High Hopes: How High Schools Respond to State Accountability Policies
}

\begin{abstract}
American public education faces increasing pressure to carry out its mission of preparing youths with the skills to compete in today's global economy and to participate constructively in a democratic society. As part of this pressure, policymakers have developed increasingly sophisticated accountability and support systems to steer schools towards improved performance. These "new accountability" approaches emphasize student performance over system inputs, focus on schools rather than school districts as units of improvement, and use public reporting of student outcomes and rewards and sanctions as ways to motivate schools to alter their curriculum and instructional practices (Fuhrman, 1999). These strategies embody two key assumptions: (a) that accountability systems can be made powerful enough to influence the behavior of schools; and (b) that schools have or will develop the capacity to identify, select, and implement policies and practices that will improve their performance. Working under these assumptions, state and national policymakers have set academic goals, defined incentives, and provided supports, expecting that these actions would motivate schools to expend resources on improving organization, curriculum, and practice, and that schools' responses would improve educational programs and instruction and, in turn, improve student outcomes.
\end{abstract}

State and national assessment results show that student performance in many elementary schools has improved over the last decade. Some researchers have argued that a portion of these gains can be attributed to the pressures generated by state accountability systems that have set standards, focused attention, and created stronger incentives for improved performance (Carnoy \& Loeb, 2004; Grissmer \& Flanagan, 1998; Grissmer, Flanagan, Kawata, \& Williamson, 2000; Hanushek \& Raymond, 2002). High schools, however, have not experienced the same positive effects, and we know little about how high school staff respond to new external accountability pressures. The study (Gross \& Goertz, 2005) reviewed in this issue of CPRE Policy Briefs provides insight into how teachers and administrators in American public high schools are influenced by and attempt to address the problems posed by standards based state accountability systems. Our analysis builds upon earlier studies that used smaller and less representative samples of secondary schools (e.g., Carnoy, Elmore, \& Siskin, 2003), sometimes agreeing with and sometimes challenging their conclusions about the effects of increased accountability and high schools.

Disciplines

Curriculum and Instruction | Educational Administration and Supervision | Educational Methods | Education Policy

Comments

View on the CPRE website. 


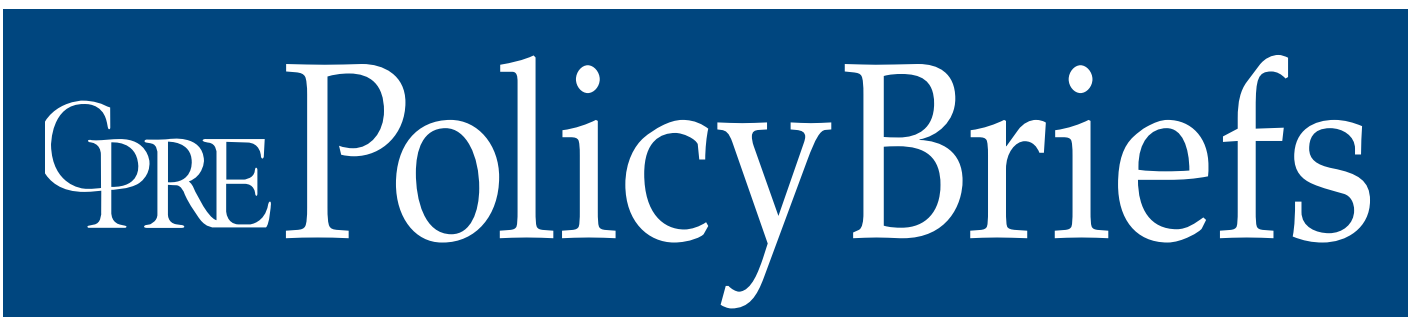

Reporting on Issues and Research in Education Policy and Finance

\section{Holding High Hopes: How High Schools Respond to State Accountability Policies}

By Margaret E. Goertz and Diane Massell

American public education faces increasing pressure to carry out its mission of preparing youths with the skills to compete in today's global economy and to participate constructively in a democratic society. As part of this pressure, policymakers have developed increasingly sophisticated accountability and support systems to steer schools towards improved performance. These "new accountability" approaches emphasize student performance over system inputs, focus on schools rather than school districts as units of improvement, and use public reporting of student outcomes and rewards and sanctions as ways to motivate schools to alter their curriculum and instructional practices (Fuhrman, 1999). These strategies embody two key assumptions: (a) that accountability systems can be made powerful enough to influence the behavior of schools; and (b) that schools have or will develop the capacity to identify, select, and implement policies and practices that will improve their performance. Working under these assumptions, state and national policymakers have set academic goals, defined incentives, and provided supports, expecting that these actions would motivate schools to expend resources on improving organization, curriculum, and practice, and that schools' responses would improve educational programs and instruction and, in turn, improve student outcomes.

State and national assessment results show that student performance in many elementary schools has improved over the last decade. Some researchers have argued that a portion of these gains can be attributed to the pressures generated by state accountability systems that have set standards, focused attention, and created stronger incentives for improved performance (Carnoy \& Loeb, 2004; Grissmer \& Flanagan, 1998; Grissmer, Flanagan, Kawata, \& Williamson, 2000; Hanushek \& Raymond, 2002). High schools, however, have not experienced the same positive effects, and we know little about how high school staff respond to new external accountability pressures. The study (Gross \& Goertz, 2005) reviewed in this issue of CPRE Policy Briefs provides insight into how teachers and administrators in American public high schools are influenced by and attempt to address the problems posed by standardsbased state accountability systems. Our analysis builds upon earlier studies that used smaller and less representative samples of secondary schools (e.g., Carnoy, Elmore, \& Siskin, 2003), sometimes agreeing with and sometimes challenging their conclusions about the effects of increased accountability and high schools.

Our study examined how 48 low-performing high schools located in 34 school districts across six states responded to state accountability policies. The six states included those with strong (California, Florida, New York, and North Carolina) and weak (Michigan and Pennsylvania) accountability systems in place in 2002-2003, the time of our fieldwork and the year preceding the implementation of the No Child Left Behind Act of 2001 (NCLB). We defined a strong accountability state as one that had sanctions for both high schools and high school students. A weak accountability state had high school assessments, but no sanctions for either schools or students. The results on state assessments were below average in all of the schools in the study. The study schools were
January 2005

RB-42

Graduate School of

Education

University of

Pennsylvania

\section{Consortium for Policy Research in Education}

University of Pennsylvania

Harvard University

Stanford University

University of Michigan

University of Wisconsin-Madison 
selected statistically from the pool of lowperforming schools to vary by school context and expected student performance. In each site, we conducted interviews with district administrators; school leaders; department leaders in English, mathematics, and foreign languages; and English and mathematics teachers. Although the sample is small, it represents a range of school and district sizes, urbanicity, and student demographics and the lessons learned may be applicable to sites other than those studied here. These lessons may benefit schools, school districts, and states that are seeking strategies to respond to the challenges of the NCLB accountability provisions.

The brief reviews the study's key findings regarding school responses to accountability, school response processes and use of external resources, and the role of district intervention and school resistance. It concludes with a discussion of the implications of the findings for policymakers.

\section{Accountability_A Stimulus for Action}

Our findings confirmed that state accountability systems can focus high school educators on reform and motivate them to address content standards and measured student performance (see, for example, Massell, Goertz, Christensen, \& Goldwasser, 2005). State accountability policies clearly shaped the goals and many of the challenges that high school staff identified, and influenced the actions that they took. To be sure, educators had goals and initiatives not related to accountability. For instance, teachers and administrators were concerned about students staying in school through graduation, success in postsecondary education, student motivation to learn, social/emotional needs, and academic performance beyond that measured by state tests. But schools, departments, or individual teachers also adopted a plethora of accountability-related initiatives, from voluntary tutoring sessions and test preparation activities to more comprehensive overhauls of curriculum and instruction.

In general, the study found high school staffs to be more responsive in California, Florida, New York, and North Carolina, states whose accountability systems had
The research reported in this brief was conducted by The Consortium for Policy Research in Education (CPRE) and funded by the Institute of Education Sciences, United States Department of Education, under Grant No. R308A960003. Opinions expressed in this brief are those of the authors and do not necessarily reflect the views of the Institute of Education Sciences, the United States Department of Education, CPRE, or its institutional members.

major consequences for both students and high schools. Intriguingly, however, we also found substantial responses from many high schools in Pennsylvania and some in Michigan, although these states had no sanctions for poorly performing students or schools at the time of our study. Indeed, state accountability systems drew attention across the states even when educators were not held directly responsible for student performance. For instance, although high school teachers did not think their job was at risk if students earned poor test results, professional pride and concern about their students, their administrators, and/or the reputation of their school motivated many to address aspects of accountability.

Furthermore, we were surprised to discover high levels of response even when educators expressed strong criticisms of their state accountability systems, a finding that in some ways contradicts previous implementation studies. Educators in many of our schools questioned the operational and technical aspects of their state's testing and accountability programs, such as the infrequency of testing, late reporting, the way progress was measured, the reasonableness of expectations for students, and the like. They also worried about negative impacts of the system on students' motivation to stay in school, staff morale, and the high school curriculum. For instance, a number of educators feared that the increased focus on state accountability had narrowed the curricula that they could offer, reducing opportunities for students whose interests were traditionally served by vocational programs, the arts, and other kinds of coursework. Some educators also worried that the tests had narrowed the content of English and mathematics courses, rigidified instructional routines, and reduced the quality of the academic experiences provided for low-performing students. 
Nevertheless, despite these fears and problems, the pressures thrust upon high schools by the accountability system generated concerted action. In fact, staff in two of the Michigan schools who were most critical of the testing and accountability policies were more active than staff in the other schools we studied there. Part of the explanation lies in our parallel finding that educators across the states had come to accept the fundamental premise of standards, and saw the aim of common, strong academic goals as compatible with good educational practice. They also had come to accept the general principle of performance-based accountability. We heard praise for common measures to calibrate teachers' expectations, and educators agreed that the public should hold students and educators to account for meeting certain outcomes. In addition, many believed that, at least in one form or another, these public policy objectives were here to stay. In the end, pressure, professional pride, and the acceptance of the intent of reform contributed to a substantial amount of response across the six states in our study.

Yet while we found a substantial amount of accountability-related action across the states, it is also crucial to recognize that there were marked variations in both the level and the nature of schools' responses within any particular state.

\section{Level of Response}

While we found a generally higher level of activity in high-stakes systems, consequences were not sufficient in and of themselves to motivate action consistently across districts or schools. Even staff in the lowest performing schools in California, Florida, New York, and North Carolina sometimes felt little press, and reacted only minimally. We also encountered both strong and weak responses among high school staff with different performance records in the low-stakes accountability systems of Pennsylvania and Michigan. Our analysis found that an extremely important factor in whether or not high school staff were active was whether their district leaders took a strong stand on accountability, mandating or in other ways encouraging their schools to take action. While a few schools resisted these pressures, district advocacy was crucial across all of our sample states.

\section{Nature of Response}

Level of response does not reveal anything about the nature or quality of the actions that high schools selected, or whether the efforts were likely to have significant effects on teaching and learning. While we did not observe instruction or attempt to evaluate implementation in any way, we analyzed whether the adopted initiatives were intended to change teaching and curriculum, and whether they were designed to reach a broad or narrow group of students, under the assumption that efforts targeted at teaching and curriculum for broader groups of students would hold greater potential for improvement.

A majority of the accountability-related actions undertaken in these high schools, in fact, did target changes in curriculum and instruction, such as aligning the curriculum to state standards or adding new basic skills and advanced academic courses (see for example, Harris, Prosky, Bach, Heilig, \& Hussar, 2005). Efforts to improve students' ability to read were undertaken in the majority of our schools. Of course, reading is prerequisite for success in high school academic courses, and reading problems are highlighted by state tests, even in fields like mathematics. Action in this realm ranged from special reading courses or remedial reading programs to the creation of a reading department in one California high school. Another major area of activity was support programs like tutoring and test preparation. Finally, schools adopted many organizational changes, such as block scheduling and daily, sustained silent reading time.

However, the reported actions ranged from "quick fixes" that were marginal to classroom practice and of limited impact, to more fundamental efforts to improve the core technology of teaching for a broad group of students. For example, before- or after-school tutoring programs did not challenge regular instructional practice, and typically were not required for students. The ubiquitous testpreparation activities usually did not lead to major changes in curriculum or instruction; test prep was often portrayed as an addition to regular lessons. Teachers typically selected their own professional development activities, influenced by their particular interests or perceptions of need rather than by common, 
schoolwide goals or visions of instruction. Similarly, organizational changes like sustained silent reading time were peripheral to regular instruction. Some schools adopted block scheduling in an effort to change teachers' instructional practices, but others used it to provide time for additional services, like counseling.

These kinds of incremental or marginal efforts stand in sharp contrast to the more comprehensive initiatives we found in some high schools. For example, one school rewrote the regular curriculum for its lowest level 10th-grade English class. Deeper curriculum changes were also seen in some efforts to rewrite and align curricula to state standards, and to alter the pacing and coverage of existing courses. One school adopted an entirely new integrated math curriculum for grades 9-12. Another school adopted a comprehensive school reform model with organizational changes intended to complement new instructional strategies. Ninthgrade academies or teams were introduced in some schools in an effort to improve the academic and social experiences for incoming freshmen. Unfortunately, however, we found that these more far-reaching change initiatives were rare occurrences; incremental and marginal efforts dominated how high schools responded to the accountability pressures.

So if accountability design alone is not sufficient to drive consistent, comprehensive action across high schools, and actions that more deeply influence instruction, we must ask: What is the mix of factors that leads school staff to respond with more promising actions? A partial answer lies in how schools did or did not organize themselves to search for improvement ideas.

\section{Searching for Solutions}

The study found that the decision-making and search processes in a majority of our sample of high schools were often haphazard and left up to individual teachers acting on their own initiative-in other words, not well organized (Gross, Kirst, Holland, \& Luschei, 2005). This finding ran contrary to our expectations; the literature on high schools engaged in reform suggests that departments play a major role in the school improvement process (McLaughlin \& Talbert, 2001; Siskin
1994; Siskin \& Little, 1995). This was clearly not the case in most of our high schools. While departments sometimes played a vital role in the social and professional lives of teachers, administrators rarely distributed decision-making authority to their departments, and teachers rarely described their departments as the loci of power in their schools. Teachers in many schools reported that their departments met infrequently or on an "as needed" basis. Rather than providing a forum for collective decision making about instruction and instructional change, most department meetings focused on administrative matters and the distribution of information about school and district policies and professional development opportunities. Similarly, while many of the schools in our study created schoolwide committees to develop state-mandated school improvement plans or to conduct needs analysis and planning as part of the accreditation process, these committees rarely played major roles in school decision-making and improvement processes.

By and large, teachers in these high schools decided independently whether to make changes in their practice, curriculum or materials. And when teachers acted on their own, they tended to meet accountability demands by adopting basic test prep strategies. In a few cases, groups of teachers, such as those who taught Algebra 1 or ninth-grade English, worked together to align their materials and instruction with state standards and assessments and/or with each other. But most often, a teacher's actions impacted only her classroom and, at times, only a small group of students. These individual decisions, while significant and in some instances constituting the major improvement efforts being made in a school, did not add up to schoolwide reform efforts.

In addition to the individualistic nature of decision making, questions arose about whether teachers had the knowledge and skills needed to develop effective responses to the external demands of accountability, and whether schools addressed capacity issues. For example, teachers and administrators in 28 of our schools identified teacher skill or commitment as problems. High school teachers' ability to develop students' 
reading skills was of particular concern, given that many students were entering the ninth grade with an elementary-level reading ability and were expected to perform at high levels on state exams. High school teachers typically are not trained to teach basic reading skills, and this may explain why several high schools created separate remedial reading classes for students.

But while a majority of our schools recognized these problems, only 10 described any schoolwide or departmental effort to address them. For instance, in many schools, administrators' management of instruction was quite distant from the classroom. While some instructional issues received a great deal of attention, such as student course failure rates in schools with severe dropout problems, veteran teachers said that administrators rarely interacted with them about their practice. In addition, most department chairs felt powerless to make decisions about curriculum and instruction, or were uncomfortable critiquing their peers or trying to exert influence on teaching practices. Classroom teachers did share ideas with their colleagues, activities that were often facilitated by physical proximity in the school building or by a common lunch period (rather than department meetings). But it was extremely rare to find high school teachers visiting each other's classrooms or modeling instruction for one another.

Accountability policies theorize that once school staffs have identified their needs, they will organize themselves to search for new strategies to improve student performance. Since current accountability expectations challenge the traditional missions of the comprehensive high school and their expectations for students (Siskin, 2004), we anticipated that staff would seek information from outsiders who could share new strategies for meetings these targets. We found, however, that while the press from state accountability focused schools on student achievement, it did not lead them to look beyond schoolhouse doors for information on effective instructional strategies. Rather, teachers drew heavily on their own experience or the experience of their colleagues to solve problems. Schools and teachers faced both external and internal barriers to accessing information.
Teachers in rural areas did not have physical access to professional development opportunities outside their district. Teachers and principals reported that time constraints and tight budgets limited their ability to attend conferences and workshops. And many teachers and administrators did not seem aware that they should, or could, look beyond themselves or their colleagues for help. In some cases, educators simply did not know other ways to search for information about new instructional strategies.

Another premise of the new accountability policies, that schools would use data to guide change, also did not materialize in many schools. We found some consistent use of data, particularly in North Carolina, where the assessments were directly linked to high school course content and results were returned to teachers in a very timely fashion. But in other states, like Michigan, some teachers had never even seen their students' test results. The lack of data use we found in many states stemmed in part from the infrequency of tests at the high school levelstate tests were administered once per year, and often only once during the high school years. The lack of teacher training in the use of test data to analyze and address weaknesses in individual student performance was also a factor in transforming the theory of data use in standards-based reform into practice.

In the end, few schools described coherent efforts to bring new ideas or information on curriculum and instruction to their teachers. Those that did seemed to have a history of such efforts, appearing to confirm earlier research that it takes capacity to build capacity in high schools (Carnoy, Elmore, \& Siskin, 2003; Debray, Parson, \& Avila, 2003; Hatch, 2002).

\section{External Information and Support}

While the vast majority of responses to accountability in our high schools were based on internally generated ideas, our study did reveal a few avenues through which outside information and support entered into the process. Of course, teachers brought information to the table from their professional development experiences, as did principals who attended workshops and conferences. It 
is likely that these experiences informed the choices they made during internal discussions.

Some schools did work more directly with outside assistance providers. For example, California and North Carolina created external support structures directed at their lowest performing schools. North Carolina hired, trained, and assigned school support teams composed of veteran administrators and subject matter specialists to work with low-performing high schools for an academic year. California gave struggling high schools grants to hire external evaluators to help develop and implement the schools' improvement plans, under a program known as the Immediate Intervention/Underperforming Schools Program (II/USP). A few of our study schools developed relationships with local universities, regional education centers, comprehensive school reform providers, or other outside providers.

School districts, however, were the most prominent as well as the most influential external agents in our study sites (see, for example, Weinbaum, 2005). They not only stimulated high schools to act on behalf of accountability, but also guided the kinds of actions schools took. Teachers and administrators in more than half of our high schools reported that district staff either suggested or required the use of one or more of the improvement strategies in place in their schools. Some districts mandated the use of programs, instructional strategies, or curriculum by all, or by low-performing, high schools, or they offered unsolicited suggestions of what schools could do. Other times, schools requested help from their central office staff, who drew from their knowledge base or sought out new ideas to help the schools.

Active districts tended to be more prescriptive, directing high schools to adopt specific strategies and monitoring the implementation of these practices. Active districts also focused on the goal of higher student performance, generally on the state assessments. Central offices developed curriculum and pacing guides to align school-level instruction to state standards. A few districts initiated quarterly benchmark examinations to provide feedback on student performance on the standards. Some assigned instructional coaches or content area specialists to develop strategies to address their schools' needs.

However, many districts in our study were not proactive on behalf of improvement in the high schools. For some, elementary and middle schools took priority, and high schools were left to operate quite autonomously. In other districts, central office staff viewed themselves as one of a variety of external resources available whenever schools requested help. But since they responded to what schools perceived as their own needs, district support addressed a wide range of goals, of which improving student performance was only one. Just as with schools, we encountered active and more passive districts within high- and low-stakes environments. Little academic research has explored what motivates and helps district organizations to intervene on behalf of state accountability goals, particularly at the high school level. Our study sheds some light on this question.

\section{Active District Intervention}

Three factors appear to be related to whether districts pressed their high schools to take actions to increase student performance. One was the prior performance of the high school. Those districts that had particularly low-performing high schools as measured by their state accountability system were more likely to take action with those schools, especially in the four states that had strong sanctions for low-performing high schools or students.

However, a second factor interacted with school performance to influence district responses: the size of the district central office (see also, for example, Hannaway \& Kimball, 2001). Did the district have sufficient human resources to work with its high schools on an ongoing basis? For example, in one study district in North Carolina with a low-performing school, the small size of the central office made it difficult for staff to provide the school with a high level of support. The few staff members were consumed with providing schools with the basics of school operation-personnel, finance, materials, and information-and with responding to the testing and data requirements of the state 
accountability system. Yet even large districts did not always have sufficient resources to work with all of their schools. In Florida, for example, county districts with large staffs but also large numbers of high schools targeted their assistance to their lowest performing ones, those that received state accountability grades of $\mathrm{D}$ and $\mathrm{F}$, because they were subject to state sanctions. Middle-performing high schools received limited support, although they were in jeopardy of being designated as in need of improvement under NCLB.

A third factor, district leadership, was also critical, particularly the presence of a few key administrators who established school improvement as a goal, identified a set of improvement strategies, and saw the district's role as directing schools to embrace these strategies. Districts with leaders who were actively supportive of their state accountability system, regardless of the strength of that system, the size of the district office, or the relative performance of their high schools, often stimulated more active responses in their schools. A small district in Pennsylvania illustrates the point. When it was placed on the state warning list for poor performance, the long-time superintendent there decided that his earlier approach of delegating responsibility for the design of school improvement initiatives to the schools had failed. He started to recentralize control over the schools, and held them accountable for raising scores on the Pennsylvania System of School Assessment (PSSA). This led the high school principal to do the same, and to implement strategies and discussions centered around improving student achievement on PSSA. Similarly, a small district in North Carolina set high expectations for its schools, used test score data to focus teachers and schools on student performance, and directed its limited resources to areas with the greatest need. Another district in that state pushed even its highest performing schools to raise the percentage of students meeting state standards. Superintendents in these small districts use their "bully pulpit" to focus attention on issues.

\section{School Resistance}

A high level of district activity did not always trigger change initiatives in high schools. Some study schools grudgingly adopted district improvement efforts, while others resisted them outright. A number of schools at the higher ends of the accountability spectrum in our sample felt they could afford to ignore the press of external accountability. For example, a North Carolina district undertook a series of actions to improve high school instruction. One school was very responsive to district initiatives, but staff in a second district high school felt that since students had performed well on state exams, they could ignore these efforts. They also thought that they held higher goals and standards than the state, and had a forceful principal who enabled them to operate more independently. At the other end of the spectrum, two low-performing California schools did little in response to district pressure and support in part because of low staff morale, a cynical view of state policy expectations, and the feeling that consequences would never really befall their students or themselves.

\section{Conclusions}

One can draw several conclusions from our research in these 48 underperforming high schools. One is that accountability can be a powerful force for change in high schools, despite the conventional image of high schools as recalcitrant organizations. But the response of high schools to external accountability depends in part on the ability and willingness of their staff to bring in fresh ideas to meet the challenges posed by policies that ask them to educate all students to high levels of academic achievement. As one scholar wrote:

High schools ... are being asked to take on a new task-something they were not designed to do-to prepare students for a defined minimum academic standard, and to get all students to graduate by achieving that standard. We have certainly not organized high schools so that all students would take the same content, or meet the same standards to graduate. In fact, comprehensive high schools were historically designed to do precisely the opposite; since the highly influential midcentury Conant report, their design imperative has been to serve democratic purposes and accommodate diverse student populations by creating a wide range of programs, and a differentiated curriculum. (Siskin, 2003, pp. 176-177) 
This agenda poses new challenges for high schools, and demands new solutions that often reach beyond teachers' and administrators' current capacities, such as in teaching basic reading skills.

Further, although research on well-functioning high schools shows, as indicated previously, that departments can play an important role in change processes, the high schools in our study, performing below expectations, did not have strong departments or other formal mechanisms for discussing or changing instructional practice. Finding ways to strengthen organizational authority, build structures, and create a culture of communication around instructional issues, needs priority. Just as landscape architects will follow trampled grass around public buildings to determine where to install sidewalks, developing capacity in these kinds of schools may require mapping and making better use of informal channels of communication while more formal mechanisms are being strengthened.

Districts, certainly, were the most important external organizations influencing these high schools. While in recent years questions have been raised about the efficacy of district administration, our work on this sample of below-average high schools concluded that central offices were vital in determining whether or not state policy goals were transmitted into school-level actions. Moreover, districts were the main sources of guidance and support for high schools, far outdistancing third-party providers in helping high schools search for solutions. While thirdparty providers are extremely common at the elementary and middle school levels, we found the "supply" of such support was surprisingly thin across our sample of schools. Who can these schools turn to for new ideas and support to handle the challenges they face?

While one reasonable solution may be expanding the numbers of third-party providers, districts are already ubiquitous, and have significant institutional power and authority over schools. Building district capacity, and finding effective incentives for their intervention in high schools, is critical to school improvement. In addition to its focus on schools, NCLB holds districts accountable for the performance of their students and responsible for assisting schools that do not meet state standards. Under the law, districts must provide ongoing technical assistance as schools develop and implement school improvement plans. They are to help schools analyze student achievement data, implement professional development, and put in place a new curriculum or instructional practices that have shown evidence of effectiveness. Districts that do not themselves meet performance expectations can be subject to state intervention.

But will these mandates and incentives be sufficient to stimulate more, and more effective, district guidance to high schools? Our research here suggests, at least, that higher stakes alone may be insufficient to spur consistent action across districts (or schools, for that matter); activism is more than a matter of mandates-it is deeply intertwined with the capabilities of people and their organizations to respond, their knowledge, their resources, and their motivations. Motivation to respond is influenced in part by how district and school staff perceive their standing in the accountability ratings and whether they view the accountability system as too demanding or sufficiently demanding or not demanding enough. Response is also influenced by capacity. Districts need strong and stable leaders and staff who are knowledgeable about high schools and improvement strategies in those particular institutions. Leadership turnover is a serious problem, particularly in big cities. For instance, Michigan recently reported that in 2003-2004, the rate of retirement of superintendents was double that of the previous year. Fewer people are applying for these positions, citing in part the pressures under NCLB (MacDonald, 2004). Accountability policies often ignore or give minimal attention to these district issues, and NCLB is no exception. States must strengthen 
the capacity of school districts, just as they expect districts to build the capacity of their low-performing schools, or the new accountability systems will not bring the improvements their architects envisioned.

\section{About the Authors}

Margaret E. Goertz is a Professor of Education Policy at Penn's Graduate School of Education and a Co-Director of CPRE. She has conducted extensive research on state education policy, state teacher testing policies, and state and federal policies for specialneeds students. She is now co-investigator of an evaluation of Title I accountability systems and school improvement efforts. Her many publications include articles and reports on school finance, policy implementation, district-level capacity building, and state accountability and assessment policies.

Diane Massell is a Senior Research Associate with CPRE at the University of Michigan, Ann Arbor. In addition to her work on high schools, she is currently conducting research on elementary schools and their

The full report of this study entitled Holding High Hopes: How High Schools Respond to State Accountability Policies, edited by Betheny Gross and Margaret E. Goertz, will soon be available on CPRE's website, www.cpre.org. environments for the Study of Instructional Improvement, based at the University of Michigan's School of Education. Her career has centered broadly on the impacts of government education policies and their influence over schooling practices.

\section{References}

Carnoy, M., Elmore, R., \& Siskin, L. S. (2003). The new accountability: High schools and highstakes testing. New York: RoutledgeFalmer.

Carnoy, M., \& Loeb, S. (2004). Does external accountability affect student outcomes? A cross-state analysis. In S. H. Fuhrman \& R. F. Elmore (Eds.), Redesigning accountability systems for education (pp. 189-219). New York: Teachers College Press.

Debray, E., Parson, G., \& Avila, S. (2003). Internal alignment and external pressure: High school responses in four state contexts. In M. Carnoy, R. Elmore, \& L. S. Siskin (Eds.), The new accountability: High schools and highstakes testing (pp. 55-85). New York: RoutledgeFalmer.

Fuhrman, S. H. (1999). The new accountability (CPRE Policy Brief No. RB-27). Philadelphia: Consortium for Policy Research in Education.

Grissmer, D., \& Flanagan, A. (1998). Exploring rapid achievement gains in North Carolina and Texas. Washington, DC: National Education Goals Panel.

Grissmer, D., Flanagan, A., Kawata, J., \& Williamson, S. (2000). Improving student achievement: What state NAEP test scores tell us (RAND Publication No. MR-924-EDU). Santa Monica, CA: RAND.

Gross, B., \& Goertz, M. E. (Eds.). (2005). Holding high hopes: How high schools respond to state accountability policies. Philadelphia: Consortium for Policy Research in Education. 
Gross, B., Kirst, M., Holland, D., \& Luschei, T. (2005). Got you under my spell? How accountability policy is changing and not changing decisionmaking in high schools. In Betheny Gross \& Margaret E. Goertz (Eds.), Holding high hopes: How high schools respond to state accountability policies. Philadelphia: Consortium for Policy Research in Education.

Hannaway, J., \& Kimball, K. (2001). Big isn't always bad: School district size, poverty, and standards-based reform. In S. H. Fuhrman (Ed.), From the capitol to the classroom: Standards-based reform in the states. One hundredth yearbook of the National Society for the Study of Education: Part II (pp. 99-123). Chicago: National Society for the Study of Education.

Hanushek, E. A., \& Raymond, M. E. (2002). Improving educational quality: How best to evaluate our schools. In Y. Kodrzycki (Ed.), Education in the 21st century: Meeting the challenges of a changing world (pp. 193224).Boston: Federal Reserve Bank of Boston.

Harris, D., Prosky, M., Bach, A., Heilig, J. V., \& Hussar, K. (2005). Overview of actions taken by high schools to improve instruction. In Betheny Gross \& Margaret E. Goertz (Eds.), Holding high hopes: How high schools respond to state accountability policies. Philadelphia: Consortium for Policy Research in Education.

Hatch, T. (2002). When improvement programs collide. Phi Delta Kappan, 93(8), 626634,639 .

MacDonald, C. (2004, August 2). Superintendent turnover rises: Shortage of top execs could hurt student achievement. The Detroit News, p. 01A. Retrieved January 7, 2005, from http://www.detnews.com/2004/schools/04 08/02/a01-229483.htm

Massell, D., Goertz, M. E., Christensen, G., \& Goldwasser, M. (2005). The press from above, the pull from below: High school responses to external accountability. In Betheny Gross \& Margaret E. Goertz (Eds.), Holding high hopes: How high schools respond to state accountability policies. Philadelphia: Consortium for Policy Research in Education.
McLaughlin, M. W., \& Talbert, J. E. (2001). Professional communities and the work of high school teaching. Chicago: University of Chicago Press.

Siskin, L. S. (1994). Realms of knowledge: Academic departments in secondary schools. Washington, DC: Falmer Press.

Siskin, L. S. (2003). When an irresistible force meets an immovable object: Core lessons about high schools and accountability. In M. Carnoy, R. Elmore, \& L. S. Siskin (Eds.), The new accountability: High schools and high-stakes testing (pp. 175-194). New York: RoutledgeFalmer.

Siskin, L. S. (2004). The challenge of the high schools. In S. H. Fuhrman \& R. F. Elmore (Eds.), Redesigning accountability systems for education (pp. 167-188). New York: Teachers College Press.

Siskin, L. S., \& Little, J. W. (Eds.). (1995). The subjects in question: Departmental organization and the high school. New York: Teachers College Press.

Weinbaum, E. (2005). Stuck in the middle with you: District response to state accountability. In Betheny Gross \& Margaret E. Goertz (Eds.), Holding high hopes: How high schools respond to state accountability policies. Philadelphia: Consortium for Policy Research in Education. 


\section{Related Publications}

The following is a list of selected publications reporting on research conducted by the Consortium for Policy Research in Education. All research reports and policy briefs are available for download on CPRE's website, www.cpre.org. For print copies of research reports, policy briefs, and journal articles please email (cpre@gse.upenn.edu) or call (215-573-0700) with your requests.

Assessment and Accountability Across the 50 States (Margaret E. Goertz and Mark C. Duffy, 2001, RB-33).

Assessment and Accountability in the 50 States (Margaret E. Goertz and Mark C. Duffy, 2001, RR-046).

Do Higher State Test Scores in Texas Make for Better High School Outcomes? (Martin Carnoy, Susanna Loeb, and Tiffany L. Smith, 2001, RR-047).

Does External Accountability Affect Student Outcomes? A Cross-State Analysis (Martin Carnoy and Susanna Loeb, 2003). Article appeared in Education Evaluational and Policy Analysis.

Holding Schools Accountable: Is It Working? (Richard F. Elmore and Susan H. Fuhrman, 2001). Article appeared in Phi Delta Kappan.

The New Accountability (Susan H. Fuhrman, 1999, RB-027).

The New Accountability: High Schools and High-Stakes Testing (Martin Carnoy, Richard Elmore, and Leslie Santee Siskin, Policy Brief, in press).

Patterns of Responses in Four High Schools Under State Accountability Policies in Vermont and New York (Elizabeth DeBray, Gail Parson, and Katrina Woodworth, 2001). Chapter in From the Capitol to the Classroom: Standards-Based Reform in the States, edited by Susan H. Fuhrman.

Redesigning Accountability Systems for Education (Susan H. Fuhrman, 2003, RB-38).

When Accountability Knocks, Will Anyone Answer? (Charles Abelmann and Richard F. Elmore, with Johanna Even, Susan Kenyon, and Joanne Marshall, 1999, RR-042).

\section{Books}

All Else Equal: Are Public and Private Schools Different? (Edited by Luis Benveniste, Martin Carnoy, and Richard Rothstein, 2003). Available from RoutledgeFalmer (www.routledge.com).

The New Accountability: High Schools and High Stakes Testing (Edited by Martin Carnoy, Richard Elmore, and Leslie Santee Siskin, 2003). Available from RoutledgeFalmer (www.routledge-ny.com).

Redesigning Accountability Systems for Education (Edited by Susan H. Fuhrman and Richard Elmore, 2004). Available from Teachers College Press (www.tcpress.com). 


\section{Nondiscrimination Statement}

The University of Pennsylvania values diversity and seeks talented students, faculty, and staff from diverse backgrounds. The University of Pennsylvania does not discriminate on the basis of race, sex, sexual orientation, religion, color, national or ethnic origin, age, disability, or status as a Vietnam era veteran or disabled veteran in the administration of educational policies, programs, or activities; admissions policies, scholarships, or loan awards; and athletic or University-administered programs or employment. Questions or complaints regarding this policy should be directed to Executive Director, Office of Affirmative Action, 1133 Blockley Hall, Philadelphia, PA 19104-6021 or 215-898-6993 (Voice) or 215-898-7803 (TDD).

\section{GRE Brifery}

Graduate School of Education University of Pennsylvania 3440 Market Street, Suite 560

Philadelphia, PA 19104-3325

\section{About CPRE}

The Consortium for Policy Research in Education (CPRE) studies alternative approaches to education reform in order to determine how state and local policies can promote student learning. Currently, CPRE's work is focusing on accountability policies, efforts to build capacity at various levels within the education system, methods of allocating resources and compensating teachers, instructional improvement, finance, and student and teacher standards. The results of this research are shared with policymakers, educators, and other interested individuals and organizations in order to promote improvements in policy design and implementation.

CPRE unites five of the nation's leading research institutions to improve elementary and secondary education through research on policy, finance, school reform, and school governance. Members of CPRE are the University of Pennsylvania, Harvard University, Stanford University, the University of Michigan, and the University of Wisconsin-Madison.

CPRE Policy Briefs are published by CPRE. To learn more about CPRE research or publications, please call 215-573-0700 or access CPRE publications at www.cpre.org; www.wcer.wisc.edu/cpre/; or www.sii.soe.umich.edu.
NON PROFIT

U.S. POSTAGE

PAID

PERMIT NO. 2563

PHILADELPHIA, PA 